\title{
KAMIENNE DZIEDZICTWO WCZESNOPIASTOWSKIEJ ARCHITEKTURY
}

\author{
THE STONE HERITAGE OF EARLY-PIAST \\ DYNASTY ARCHITECTURE
}

\begin{abstract}
In the article I draw attention to the lack of consistency in descriptions of the rock material used to build the first structures in the early Piast state. The role and importance of the types of stone material used at that time are unappreciated, if not downright ignored. I emphasize the fact that the main material used in early-medieval building construction were glacial erratics, sometimes representing up to $98 \%$ of the entire building material. Other rocks used in constructing buildings included travertine, sod iron ore, limestone and gypsum. However, I have devoted a lot of attention to the Miocene quartzite sandstone excavated in the early stages of Polish statehood from a quarry in Brzeźno near Konin. In the summary, I suggest possible time scales for the use of part of the rock material.
\end{abstract}

Keywords: glacial erratics, mortar, quartzite sandstone, sand, gypsum, limestone, monumental architecture.

\section{WPROWADZENIE}

Badanie surowca skalnego użytego do budowy kamiennych wczesnopiastowskich obiektów sakralnych i świeckich sięga, co najmniej, drugiej połowy XIX wieku (Skoczylas 1990). Mimo to jeszcze w dniu dzisiejszym niewiele pisze się o materiale budowlanym wykorzystywanym do wznoszenia na ziemiach Polski pierwszych kamiennych budowli. Problem ten nabiera obecnie nowego znaczenia i wyrazu, kiedy z okazji uczczenia 1050. rocznicy chrztu na ziemiach polskich pojawiło się wiele publikacji historycznych, a przede wszystkim archeologicznych.

W świetle tych samych znanych, niejednokrotnie opisywanych źródeł historycznych oraz nowych odkryć i ustaleń z zakresu archeologii powstają nowe kon-

* Wydział Nauk Geograficznych i Geologicznych UAM, Instytut Geologii, ul. Bogumiła Krygowskiego 10, 61-680 Poznań, skocz@amu.edu.pl. 